\title{
BEHAVIOR OF LATERALLY LOADED PILES IN COHESIVE SOILS
}

\author{
P. Jeyalakshmi ${ }^{1}$, V. Jeyanthi Vineetha ${ }^{2}$ \\ ${ }^{1}$ Undergraduate Student, Civil Department, V V College Of Engineering, Tamil Nadu, India \\ ${ }^{2}$ Assistant Professor, Civil Department, Ponjesly College of Engineering, Tamil Nadu, India
}

\begin{abstract}
Pile foundations are often required to resist lateral loading. Lateral loads come from a variety of sources including wind, earthquakes, waves, and ship impacts. So, it is important to know the lateral load resistance capacity of pile foundation. This requires estimation of ultimate loads based on which safe working loads will be assessed and also estimation of pile deflections to ensure that serviceability aspects are accounted in the design Several methods are available for predicting the ultimate lateral resistance to piles in clay soil. However, these methods often produce significantly different ultimate resistance values. This makes it difficult for practicing engineers to effectively select the appropriate method when designing laterally loaded piles in clay soil. In this paper, lateral load behavior of single piles in clay soil was studied, for different L/D ratio by changing the diameter and length of pile. The analysis was carried out by considering free head pile. The influence of soil type, effect of pile length and pile diameter on the pile response was observed and the results obtained by IS2911Part1 (sec2) were compared with the Broms method. Also deflection and lateral load were calculated for a typical pile for various $L / D$ ratio and their results were presented
\end{abstract}

Keywords: Pile, Cohesive soil, Lateral load, Broms method, Free head pile.

\section{INTRODUCTION}

Piles are structural members that are made of steel, concrete or timber. They are used to build deep foundations and which cost more than shallow foundations. Despite the cost, the use of pile often is necessary to ensure structural safety. Some time piles are subjected to lateral load, for example piles used in quay and harbor structure. The sources of lateral load on harbor structure are impact of ship and wave action and off shore structures are also subjected to wind and wave. High rise building, tower are subjected to lateral load due to wind and earth quake forces. So, it is important to know the lateral load resistance capacity of pile foundation. Several methods are available for predicting the ultimate lateral resistance to piles in cohesive soils. However, these methods often produce significantly different ultimate resistance values. This makes it difficult for practicing engineers to effectively select the appropriate method when designing laterally loaded piles in cohesive soils. Broms (1964-a) established methods containing graphical relationships for obtaining the ultimate lateral resistance for short piles and ultimate resistance moment, ultimate lateral resistance for long piles driven into cohesive soils. For each free and fixed pile head, he also presented methods for calculating the lateral deflection at working load based on the concept of the modulus of horizontal subgrade reaction, which assumed to be constant with depth. Broms (1964-b) established methods containing graphical relationships for determination of ultimate lateral resistance for short pile, ultimate lateral resistance and ultimate resistance moment for long piles for both fixed and free head condition in cohesionless soils. He also stated methods to determine the lateral deflection at working load, assuming that the co-efficient of subgrade reaction increases linearly with depth. Bowles (1974) produced a computer program to analyze the problem of laterally loaded piles with ability of applying axial loads on the pile. This program processed general cases of a pile, fully or partially embedded and for vertical and battered piles. Prakash and Kumar (1996) developed a method to predict the load deflection relationship for single piles embedded in sand and subjected to lateral load, considering soil nonlinearity based on the results of 14 full-scale lateral pile load tests.

\section{OBJECTIVES}

The objectives of this paper were

- $\quad$ To find the lateral load carrying capacity of single pile in clay soil.

- $\quad$ To compare the load carrying capacity of pile by IS 2911 part 1(sec2) with Broms method.

- $\quad$ To find the effect of diameter of the pile on lateral load capacity.

- $\quad$ To find the effect of length of the pile on lateral load capacity.

\section{METHODOLOGY}

The various methods employed in this paper were discussed with the results in the following topics.

\subsection{Effect of Diameter of the Pile on Lateral Load}

\section{Capacity}

To study the effect of diameter on lateral load capacity, 20 $\mathrm{m}$ length of piles of different diameters such as $0.50 \mathrm{~m}$, $0.60 \mathrm{~m}, 0.70 \mathrm{~m}, 0.80 \mathrm{~m}, 0.90 \mathrm{~m}$, and $1.00 \mathrm{~m}$ were considered. The results are given in Table 1, which indicates that lateral load capacity increases with increasing diameter of the pile (Fig.1\& 2). This was due to the increase in surface area. Also the pile stiffness, EI, increases with increase in moment of inertia I which depends on the 
diameter of pile. The lateral load capacity of pile obtained from IS2911 Part1 (sec2) was significantly less when compared with Broms method.

\subsection{Effect of Length of the Pile on Lateral Load}

\section{Capacity}

To study the effect of length of the pile on lateral load capacity, $0.50 \mathrm{~m}$ diameter piles of different lengths such as
$20 \mathrm{~m}, 16.7 \mathrm{~m}, 14.3 \mathrm{~m}, 12.5 \mathrm{~m}, 11.1 \mathrm{~m}$, and $10 \mathrm{~m}$ were considered. The results are given in Table2, which indicates there is no any considerable change in lateral load capacity with increase in length (Fig.3 \& 4).

Table 1: Comparison of lateral load capacity \&lateral deflection with increase in diameter

\begin{tabular}{|l|l|l|l|l|l|l|l|}
\hline \multirow{3}{*}{\begin{tabular}{l} 
Sl.No. \\
\cline { 5 - 8 }
\end{tabular}} & \multirow{2}{*}{$\begin{array}{l}\text { Length } \\
(\mathrm{m})\end{array}$} & \multirow{2}{*}{$\begin{array}{l}\text { Diameter } \\
(\mathrm{m})\end{array}$} & \multirow{2}{*}{$\begin{array}{l}\text { L/D } \\
\text { Ratio }\end{array}$} & & \multicolumn{2}{l|}{ Lateral load capacity $(\mathrm{KN})$} & \multicolumn{2}{l|}{ Lateral deflection $(\mathrm{mm})$} \\
\cline { 5 - 9 } & & & $\begin{array}{l}\text { As per } \\
\text { IS 2911 }\end{array}$ & $\begin{array}{l}\text { As per } \\
\text { Broms }\end{array}$ & $\begin{array}{l}\text { As per } \\
\text { IS2911 }\end{array}$ & $\begin{array}{l}\text { As per } \\
\text { Broms }\end{array}$ \\
\hline 1 & 20 & 0.50 & 40.00 & 1218 & 1594 & 3.5 & 6.8 \\
\hline 2 & 20 & 0.60 & 33.33 & 1924 & 2295 & 2.5 & 5.7 \\
\hline 3 & 20 & 0.70 & 28.57 & 2685 & 3124 & 2.0 & 4.9 \\
\hline 4 & 20 & 0.80 & 25.00 & 3340 & 4080 & 1.5 & 4.3 \\
\hline 5 & 20 & 0.90 & 22.22 & 4114 & 5164 & 1.2 & 3.8 \\
\hline 6 & 20 & 1.00 & 20.00 & 5206 & 6375 & 1.0 & 3.4 \\
\hline
\end{tabular}

Table 2: Comparison of lateral load capacity \&lateral deflection with increase in Length

\begin{tabular}{|c|c|c|c|c|c|c|c|}
\hline \multirow[b]{2}{*}{ Sl.No. } & \multirow{2}{*}{$\begin{array}{l}\text { Length } \\
\text { (m) }\end{array}$} & \multirow{2}{*}{$\begin{array}{l}\text { Diameter } \\
(\mathrm{m})\end{array}$} & \multirow{2}{*}{$\begin{array}{l}\text { L/D } \\
\text { Ratio }\end{array}$} & \multicolumn{2}{|c|}{ Lateral load capacity(KN) } & \multicolumn{2}{|c|}{ Lateral deflection $(\mathrm{mm})$} \\
\hline & & & & $\begin{array}{l}\text { As per } \\
\text { IS } 2911\end{array}$ & $\begin{array}{l}\text { As per } \\
\text { Broms }\end{array}$ & $\begin{array}{l}\text { As per } \\
\text { IS } 2911\end{array}$ & $\begin{array}{l}\text { As per } \\
\text { Broms }\end{array}$ \\
\hline 1 & 20.0 & 0.50 & 40.00 & 1218 & 1594 & 3.5 & 6.8 \\
\hline 2 & 16.7 & 0.50 & 33.40 & 1169 & 1594 & 3.5 & 6.8 \\
\hline 3 & 14.3 & 0.50 & 28.60 & 1108 & 1594 & 3.5 & 6.8 \\
\hline 4 & 12.5 & 0.50 & 25.00 & 1069 & 1594 & 3.5 & 6.8 \\
\hline 5 & 11.1 & 0.50 & 22.22 & 1040 & 1594 & 3.5 & 6.8 \\
\hline 6 & 10.0 & 0.50 & 20.00 & 1008 & 1594 & 3.5 & 6.8 \\
\hline
\end{tabular}

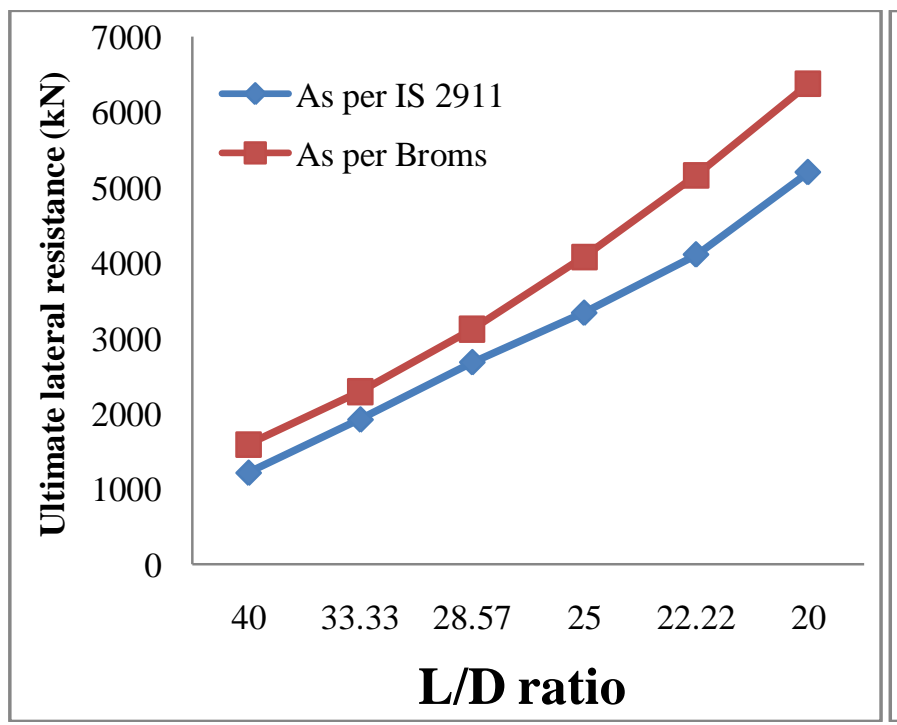

Fig 1 Ultimate lateral resistance (Increase in diameter)

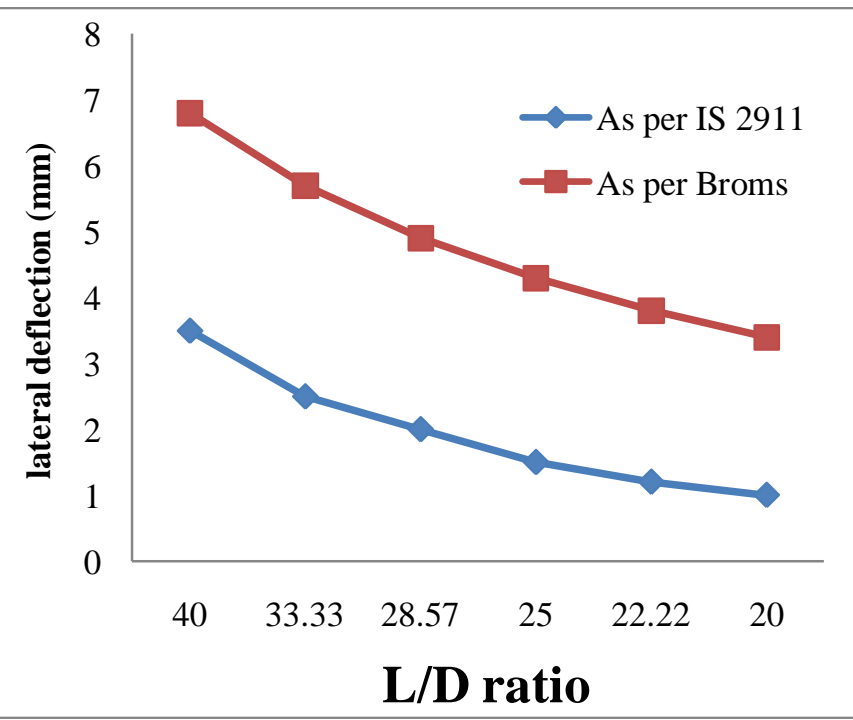

Fig 2 Lateral deflection (Increase in diameter) 


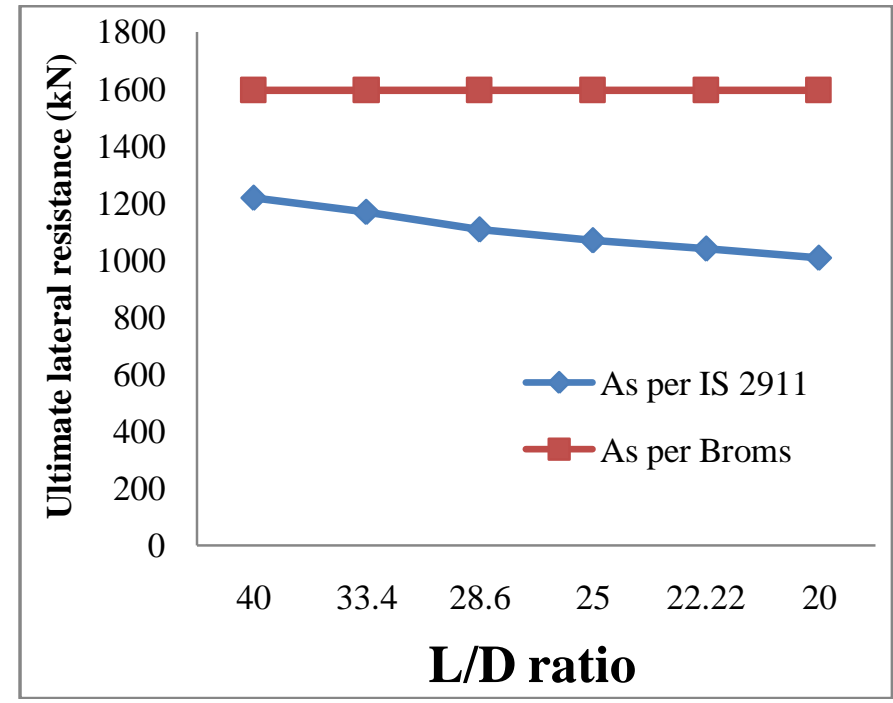

Fig 3 Ultimate lateral resistance (Increase in length)

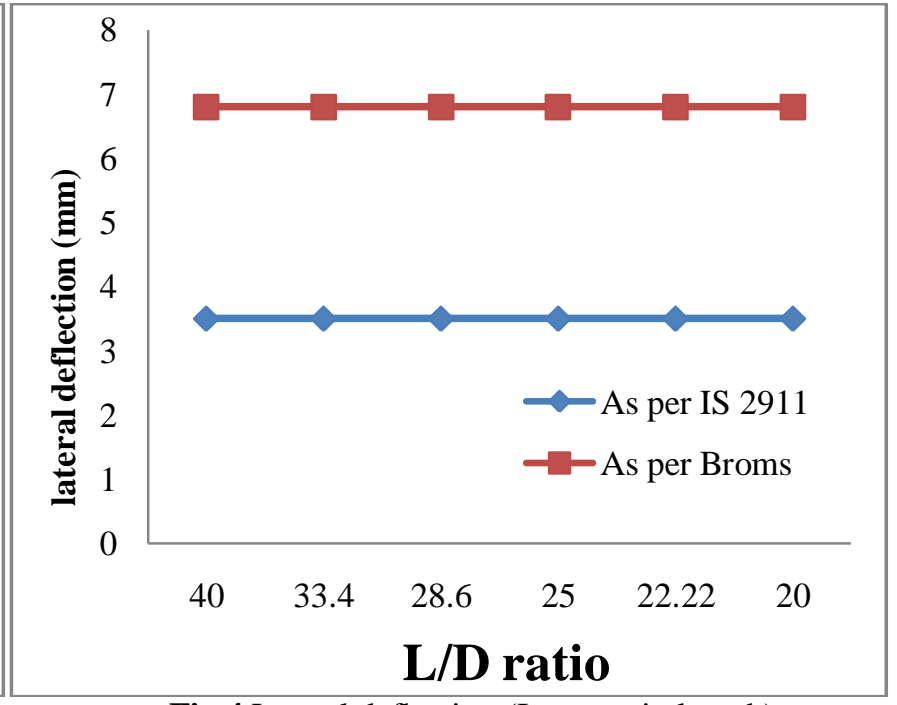

Fig 4 Lateral deflection (Increase in length)

\section{CONCLUSIONS}

From the obtained data the following conclusions were made

- The effect of pile diameter was studied and it was concluded that lateral load capacity increases with increase in diameter of the pile for same length. This was due to the increase in surface area, pile stiffness, moment of inertia and young's modulus.

- The lateral load capacity of pile obtained from IS 2911 Part1 (sec2) was significantly less when compared with Broms method.

\section{REFERENCES}

[1]. Broms, B.B. (1964a) Lateral resistance of piles in cohesive soils. Journal of Geotechnical Engineering, 90, 2763.

[2]. Broms, B.B. (1964b) Lateral resistance of piles in cohesionless soils. Journal of Geotechnical Engineering, 90, 123-156.

[3]. Bowles, J.E. Analytical and computer methods in foundation engineering. McGraw Hill Book Co. New York, 1974.

[4]. Prakash, S. and S. Kumar (1996) Non linear lateral pile deflection prediction in sand. Journal of Geotechnical Engineering, 112, 130-138.

[5]. IS : 2911 (Part 1/Sec 2) - 1979 Code of practice for design and construction of pile foundations. Bureau of Indian standards.

[6]. IS : 2911 (Part 4) - 1985 Code of practice for design and construction of pile foundations. Bureau of Indian standards. 